\title{
Synthesis of Pyrethrolone Derivatives
}

\author{
Katsuhide OKada, Michio NozakI, Yoshinori Takashima,*1 \\ Nobuji NaKatani, ${ }^{* 2}$ Yoichi NaKaTANI ${ }^{* 3}$ \\ and Masanao MATSUI \\ Department of Agricultural Chemistry, The University of Tokyo, \\ Bunkyo-ku, Tokyo 113, Japan
}

Received June 2, 1977

\begin{abstract}
A useful method of synthesis of pyrethronyl acetate (VII) and pivalate (VIII) from readily available allethrolone (II) is described.
\end{abstract}

Pyrethrolone (I) is the alcohol component of pyrethrin I and pyrethrin II, the principal constituents of the naturally occurring insecticidal "pyrethrin" esters found in Chrysanthemum cinerariaefolium." Although several routes to pyrethrolone (I) have been described, ${ }^{1 \sim 6)}$ none of them seemed suitable for practical preparation because of long sequence and inconvenience. We report here the simple conversion of readily available allethrolone [4-hydroxy-3-methyl-2-(prop-2-enyl)cyclopent2-enone] (II) into several pyrenthrolone derivatives. Allethrolone (II) is an industrially synthetic rethrolone used as an alcohol component of "allethrin"') and its conversion into several rethrolones and rethrones ${ }^{5)}$ has already been reported, but conversion into pyrethrolone (I) which contains a sensitive vinyl-diene system has not yet been done. The acetate (III) and pivalate (IV) of allethrolone were oxidized to the keto-aldehydes (V, VI) by using osmium tetroxide-sodium periodate or ozone- $\mathrm{Zn}$ $\left(\mathrm{CH}_{3} \mathrm{COOH}\right)$. The keto-aldehydes (V, VI) produced by osmium tetroxide were unstable ${ }^{5)}$ and diffucult to be purified, and when these products were used without further purification

*1 Present address: Research and Development Center, Pharmaceuticals Division, Sumitomo Chemical Co., Ltd., Takarazuka, Hyogo 665, Japan.

*2 Present address: Department of Food and Nutrition, Faculty of Science of Living, Osaka City University, Sumiyoshi-ku, Osaka 558, Japan.

*3 Present address: Department of Food and Nutrition, Ochanomizu University, Bunkyo-ku, Tokyo 112, Japan. in the next reaction (the Wittig condensation), the yield was very low. On the other hand, the aldehyde (V) prepared by ozone in good yield was easy to be purified by distillation. The Wittig condensation between the aldehyde (V) and the ylide derived from allyltriphenylphosphonium bromide in tetrahydrofuran with $n$-butyllithium as a base gave a mixture of (E)- and (Z)-olefin isomers (VII). The com-

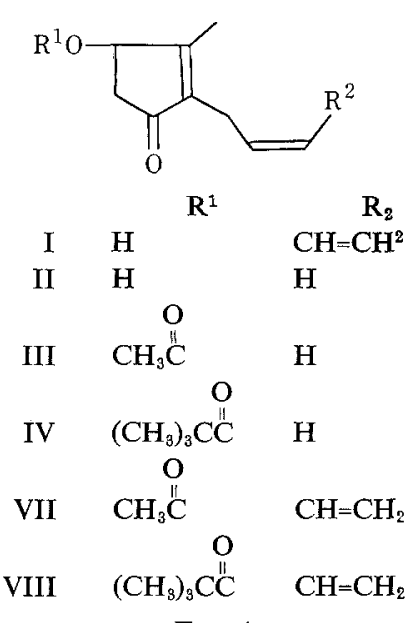

FIG. 1.

pound which would form by condensation a1 the ketone carbonyl group in (V) was no1 detected by the spectral data of the crude reaction mixture. This means that the condensation was regio-specific. The olefin was chromatographed on silica gel- $\mathrm{AgNO}_{3}$ to give the (Z)-pyrethronyl acetate (VII) and spectra. (PMR) comparison with an authentic sample ${ }^{8}$ 
and (Z)-6-(2-methyl-1, 3-dioxolan-2-yl) hexa1,3-diene(IX) prepared by a Wittig condensation under "salt-free" conditions ${ }^{2)}$ showed a close similarity. The other product eluted was determined as a mixture of the (E)- and (Z)olefin, because the PMR data for the olefinic proton $\left(\mathrm{H}_{a}\right)$ of the above mixture showed a cis-vicinal coupling ( $\delta 6.00$, characteristic of cis-double bond) and a double-doublet ( $\delta 6.20$, characteristics of trans-vicinal coupling) (Fig. 2). ${ }^{2}$ The ratio of (E)- and (Z)-isomer was
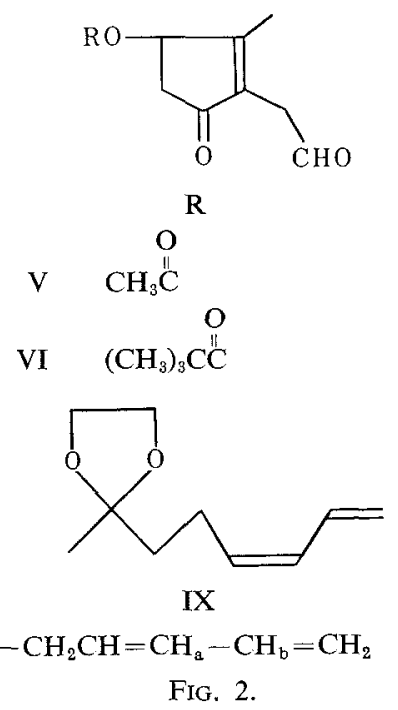

$7: 3$ as indicated by the observation of the above PMR data and the GLC analysis. Almost the same result was obtained also in the case of the pivalate (VIII).

Pyrethronyl acetate has been already converted to pyrethrolone ${ }^{9 /}$ and we are now investigating to find more efficient conditions. Some pyrethronyl esters were prepared and are under insecticidal assays. Results will be published elsewhere.

\section{EXPERIMENTAL}

Melting points are uncorrected. Unless stated otherwise, PMR spectra were determined with a JEOL JNM-MH-100 $(100 \mathrm{MHz})$ spectrometer for dilute solutions in deuteriochloroform with tetramethylsilane as an internal standard. IR spectra were measured with a Jasco IRA-1 spectrometer and mass spectra were measured with a Hitachi RMU-6L spectrometer. GLC data were obtained on a $10 \%$ Apiezon L column.
4 - (2, 2 - Dimethylpropionyloxy) - 3 - methyl - 2 - (prop- 2 enyl)-cyclopent-2-enone (IV)

Pivaloyl chloride (2, 2-dimethylpropanoyl chloride) $(25 \mathrm{~g})$ was added dropwise to an ice-cooled solution of allethrolone (II) $(35 \mathrm{~g})$ and pyridine $(21 \mathrm{~g})$ in dry benzene $(170 \mathrm{ml})$ under stirring. The solution was stirred for $12 \mathrm{hr}$ at room temperature, diluted with water $(100 \mathrm{ml})$ and extracted with ether. The organic layer was washed with dil. hydrochloric acid, water, aq. cupric sulfate, water, aq. sodium bicarbonate and water. The solution was dried over magnesium sulfate and concentrated in vacuo. The residue was distilled to give $44 \mathrm{~g}(78 \%)$ of (IV), bp $97 \sim 99^{\circ} \mathrm{C}(0.3 \mathrm{mmHg})$; IR $\nu_{\max } \mathrm{cm}^{-1}: 1730,1710,1655,1280,1150$; PMR $\delta 1.24\left(\mathrm{~s},\left(\mathrm{CH}_{3}\right)_{3}\right), 2.05\left(\mathrm{~s},=\mathrm{C}-\mathrm{CH}_{8}\right), 2.15(\mathrm{~d}-\mathrm{d}, J=3$ and $18 \mathrm{~Hz},-\mathrm{C} \underline{\mathrm{H}}$ ), 2.86 (d-d, $J=6$ and $18 \mathrm{~Hz},-\mathrm{CH} \underline{\mathrm{H}}$ ), $3.05\left(\mathrm{~d}, J=10 \mathrm{~Hz},-\mathrm{CH}_{2}-\mathrm{C}=\mathrm{C}\right), 4.83 \sim 5.24\left(\mathrm{~m},=\mathrm{CH}_{2}\right)$, $\mathrm{O}$ $5.52 \sim 6.28\left(\mathrm{~m},-\mathrm{CH}=\mathrm{C},-\mathrm{CHOCC}\left(\mathrm{CH}_{3}\right)_{3}\right)$.

2-Formylmethyl-4-acetoxy-3-methylcyclopent- 2 -enone (V)

a) By ozone. Ozone was introduced to an acetate (III) $(11.5 \mathrm{~g})$ in dichloromethane $(600 \mathrm{ml})$ at $-30^{\circ} \mathrm{C}$ until the starting material (acetate) disappeared on TLC. Then the solution was cooled at $-50^{\circ} \mathrm{C}$, and water $(9 \mathrm{ml})$ and acetic acid $(90 \mathrm{ml})$ were added under vigorous stirring. After the rise of temperature stopped, zinc powder $(60 \mathrm{~g})$ was added to the solution and the reaction mixture was stirred vigorously for $3 \mathrm{hr}$. The solid precipitate was filtered off and the filtrate was washed with cold water, dried over magnesium sulfate and concentrated in vacuo at low temperature. The yellow residue was distilled under nitrogen to give $9.6 \mathrm{~g}(84 \%)$ of (V), bp $123 \sim 129^{\circ} \mathrm{C}(0.4$ $\mathrm{mmHg}) ; \mathrm{IR} \nu_{\max } \mathrm{cm}^{-1}: 2820,2720,1735,1725,1710$, 1380, 1250, 1040, 1020, 940; PMR $\delta 9.75$ (t, $J=1.5 \mathrm{~Hz}$, CHO), 5.82 (m, CHOAc), 3.42 (d, $J=1.5 \mathrm{~Hz}$, $\mathrm{CH}_{2} \mathrm{CHO}$ ), 3.00 (d-d, $J=6$ and $18 \mathrm{~Hz}, \mathrm{CHH}$ ), 2.27 (d-d, $J=6$ and $18 \mathrm{~Hz}, \mathrm{CH} \underline{\mathrm{H}}$ ), 2.15 (s, OAc), 2.05 (s, $\left.\mathrm{CH}_{3}\right)$; MS m/e: $196\left(\mathrm{M}^{+}\right)$. It formed a 2,4-dinitrophenyl hydrazone (monohydrazone condensed at formyl group) which crystallized from ethanol-ethyl acetate as yellow needles, mp $160.5 \sim 161^{\circ} \mathrm{C}$; Anal. Found: C, 51.02; $\mathrm{H}, 4.41 ; \mathrm{N}, 14.75$. Calcd. for $\mathrm{C}_{10} \mathrm{H}_{16} \mathrm{~N}_{4} \mathrm{O}_{7}$; C, $51.06 ; \mathrm{H}, 4.29 ; \mathrm{N}, 14.89 \%$.

b) By osmium tetroxide. Powdered sodium metaperiodate $(60 \mathrm{~g})$ was added to a solution of the acetate $(30 \mathrm{~g})$ and osmium tetroxide $(0.15 \mathrm{~g})$ in tetrahydrofuran $(200 \mathrm{ml})$ and water $(15 \mathrm{ml})$, and the mixture was stirred for $24 \mathrm{hr}$ at room temperature. The solid precipitate was filtered off and the filtrate was extracted with dichloromethane. The solution was washed with water and dried over magnesium sulfate. Evaporation of the solvent gave the aldehyde which was chromatographed in benzene and ether $(1: 1)$ on silica gel to 
give $17.8 \mathrm{~g}(58.8 \%)$ of $(\mathrm{V})$ as an oil. It was spectrally identical with that obtained in (a).

\section{2-Formylmethyl-4-(2, 2-dimethylpropionyloxy)-3-methyl- cyclopent-2-enone (VI)}

a) By ozone. The aldehyde was prepared from the pivalate (IV) (15 g) in an identical manner to that described for the acetate. Evaporation of a solvent left the aldehyde (VI) $13.2 \mathrm{~g}(89 \%)$; IR $\nu_{\max } \mathrm{cm}^{-1}$ : $2820,2720,1730,1725,1705,1660,1285,1150$; PMR

$\delta 9.75(\mathrm{t}, J=1.5 \mathrm{~Hz}, \mathrm{CHO}), 5.85$ ( $\mathrm{m},-\mathrm{CHOC}$ ), 3.42 (d, $J=1.5 \mathrm{~Hz},-\mathrm{CH}_{2} \mathrm{CHO}$ ), 3.00 (d-d, $J=6$ and $18 \mathrm{~Hz}$, $-\mathrm{CHH}$ ), 2.25 (d-d, $J=3.5$ and $18 \mathrm{~Hz},-\mathrm{CH} \underline{\mathrm{H}}$ ), 2.05 (s, $\left.=\mathrm{C}-\mathrm{CH}_{3}\right), 1.25\left(\mathrm{~s},\left(\mathrm{CH}_{3}\right)_{3}\right)$.

b) By osmium tetroxide. The pivalate $(10 \mathrm{~g})$ was oxidised to an aldehyde in an identical manner to that described for the acetate. The aldehyde $(5.2 \mathrm{~g}, 51.6 \%)$ was chromatographically separated, which was spectrally identical with that obtained in (a).

\section{4-Acetoxy-3-methyl-2-[(Z)-penta-2,4-dienyl]-cyclopent-2- enone ( $V I I)$}

a) From (V) prepared by ozone. A solution of $n$-butyllithium in $n$-hexane $(1.35 \mathrm{M}, 35.5 \mathrm{ml})$ was added dropwise to a stirred suspension of allyltriphenylphosphonium bromide $(22 \mathrm{~g})$ in tetrahydrofuran $(230$ $\mathrm{ml})$ at $20^{\circ} \mathrm{C}$ under nitrogen and the resulting red solution was stirred at $20^{\circ} \mathrm{C}$ for $0.5 \mathrm{hr}$. And then the temperature of the solution was lowered to $10^{\circ} \mathrm{C}$, the aldehyde (V) $(9.4 \mathrm{~g})$ in tetrahydrofuran $(30 \mathrm{ml})$ was added to the solution in $10 \mathrm{~min}$. The mixture was stirred for $40 \mathrm{~min}$ at $10^{\circ} \mathrm{C}$ and then at $20^{\circ} \mathrm{C}$ for another $1 \mathrm{hr}$. $n$-Hexane $(200 \mathrm{ml})$ was added to a solution and the solid precipitate was filtered off. The filtrate was washed with water and dried over magnesium sulfate. Evaporation of the solvent left a residue which was chromatographed in $n$-hexane on silica gel to give the olefin $(1.6 \mathrm{~g}, 16 \%)$ as an oil and GLC showed the presence of $(Z)$ - and $(E)$-isomers in a proportion of 30:70. Further chromatography on silica gel$\mathrm{AgNO}_{3}$ gave the (Z)-olefin; IR $\nu_{\max } \mathrm{cm}^{-1}: 3080,1740$, $1715,1660,1240,1020$, 950, 905; PMR $\delta 2.05$ (s,

$$
\mathrm{O}
$$

$\left.=\mathrm{C}-\mathrm{CH}_{3}\right), 2.15\left(\mathrm{~s}, \mathrm{CH}_{3} \mathrm{CO}\right), 2.24(\mathrm{~d}-\mathrm{d}, J=3$ and $18 \mathrm{~Hz}$, $-\mathrm{CHH}$ ), 2.86 (d-d, $J=6$ and $18 \mathrm{~Hz},-\mathrm{CHH}), 3.12$ (d, $\left.J=6 \mathrm{~Hz}, \mathrm{CH}_{2}\right), 4.92 \sim 5.40(\mathrm{~m}, 3 \mathrm{H}), 5.64(\mathrm{~m}, \mathrm{AcOCH})$, 6.00 (d-d, $J=10$ and $10 \mathrm{~Hz}, \mathrm{Ha}$ ), 6.74 (d-d-d, $J=10$, 10 and $16 \mathrm{~Hz}, \mathrm{Hb})$; MS m/e $220\left(\mathrm{M}^{+}\right)$. Further elution of the chromatogram gave a mixture of $(\mathrm{E})$ - and (Z)-isomers $(1.02 \mathrm{~g})$. IR data were closely similar to those of (Z)-isomer. PMR data showed an extra signal which was characteristic of the trans-double bond. PMR $\delta 3.00$ (d, J=6 Hz, $\mathrm{CH}_{2} \mathrm{CH}=\mathrm{CH}$ ), 6.20 (d-d, $J=16$ and $10 \mathrm{~Hz}, \mathrm{Ha})$; GLC $(1.5 \mathrm{~m} \times 3 \mathrm{~mm}$ i.d. at $178^{\circ} \mathrm{C}$, carrier gas, $\left.\mathrm{N}_{2}, 1.0 \mathrm{~kg} / \mathrm{cm}^{2}\right), t_{R} 12 \mathrm{~m} 30 \mathrm{sec}$
(E), $t_{R} 13 \mathrm{~m} 30 \mathrm{sec}(\mathrm{Z}),(70: 30)$.

b) From (V) prepared by osmium tetroxide. A solution of $n$-butyllithium in $n$-hexane $(1.53 \mathrm{M}, 16.6 \mathrm{ml})$ was added dropwise to a stirred suspension of allyltriphenylphosphonium bromide $(14.4 \mathrm{~g})$ in absolute ether $(100 \mathrm{ml})$ at $0^{\circ} \mathrm{C}$ in $0.5 \mathrm{hr}$ under nitrogen and the resulting red solution was stirred for $3 \mathrm{hr}$ at $0^{\circ} \mathrm{C}$, and then the solution was transferred to a dropping funnel. It was added dropwise over $1.5 \mathrm{hr}$ to the aldehyde $(\mathrm{V}, 5 \mathrm{~g})$ in absolute ether $(50 \mathrm{ml})$ at $0^{\circ} \mathrm{C}$ under nitrogen. The mixture was stirred for $1 \mathrm{hr}$ at room temperature and the white solid was filtered off. The filtrate was washed with water dried over magnesium sulfate and concentrated in vacuo. The residue was separated by preparative thin-layer chromatography (silica gel) in benzene and ether $(17: 3)$ to give the olefin (VII) (150 mg). The PMR spectrum was closely similar to that obtained in (a). MS $m / e 220\left(\mathrm{M}^{+}\right)$, $160(\mathrm{M}-60)$.

4-(2,2-Dimethylpropionyloxy) -3-methyl-2-[(Z)-penta-2enyl]-cyclopent-2-enone (VIII)

The olefin $(1.7 \mathrm{~g}, 12 \%)$ was prepared from the aldehyde (VI) $(13.2 \mathrm{~g})$ in an identical manner to that described for the acetate by the method (a). GLC $\left(1.5 \mathrm{~m} \times 3 \mathrm{~mm}\right.$ i.d. at $195^{\circ} \mathrm{C}$, carrier gas, $\left.\mathrm{N}_{2}, 0.8 \mathrm{~kg} / \mathrm{cm}^{2}\right)$, $t_{R} 14 \mathrm{~m} 0 \mathrm{sec}(\mathrm{E}), t_{R} 15 \mathrm{~m} 10 \mathrm{sec}(\mathrm{Z}),(70: 30)$. Chromatography (silica gel- $\mathrm{AgNO}_{3}$ ) separated the olefin (VIII) as an oil, IR $\nu_{\max } \mathrm{cm}^{-1}: 2920,2860,1740,1715$, $1660,1290,1150,1000,950,905$; PMR $\delta 1.24$ (s, $\left.\left(\mathrm{CH}_{3}\right)_{3}\right), 2.05\left(\mathrm{~s}, \mathrm{CH}_{3}\right), 2.15$ (d-d, $J=3$ and $18 \mathrm{~Hz}$, $\mathrm{CHH}$ ), 2.86 (d-d, $J=6$ and $18 \mathrm{~Hz}, \mathrm{CH} \underline{\mathrm{H}}$ ), 3.16 (d, $\left.J=8 \mathrm{~Hz}, \mathrm{CH}_{2}\right), 5.30 \sim 4.90(\mathrm{~m}, 3 \mathrm{H}), 6.00(\mathrm{~d}-\mathrm{d}, J=10$ and $10 \mathrm{~Hz}, \mathrm{Ha}$ ), 6.72 (d-d-d, $J=10,10$ and $16 \mathrm{~Hz}, \mathrm{Hb}$ ); MS m/e: $262\left(\mathrm{M}^{+}\right)$. PMR data for the mixture of (E)- and (Z)-isomer eluted later showed an extra signal. PMR $\delta 3.00\left(\mathrm{~d}, J=6 \mathrm{~Hz}, \mathrm{CH}_{2}\right.$ ), 6.20 (d-d, $J=10$ and $16 \mathrm{~Hz}, \mathrm{Ha})$.

\section{REFERENCES}

1) M. Matsui and I. Yamamoto, "Pyrethroids" in "Naturally Occurring Insecticides," ed. M. M. Jacobson and D. G. Crosby, Dekker, New York, 1971.

2) L. Crombie, P. Hemesley and G. Pattenden, J. Chem. Soc. (C), 1969, 1016.

3) L. Crombie, P. Hemesley and G. Pattenden, ibid., 1969, 1024.

4) R. A. Ellison, Synthesis, 1973, 397.

5) G. Pattenden and R. Storer, J. Chem. Soc., 1974, 1603 and references cited therein.

6) R. F. Romanet and R. H. Schlessinger, J. Am. Chem. Soc., 96, 3701 (1974) and references cited therein.

7) M. S. Schechter, N. Green and F. B. LaForge, 
J. Am. Chem. Soc., 71, 3165 (1949).

8) A. F. Bramwell, L. Crombie, P. Hemesley, G. Pattenden, M. Elliot and N. F. Janes, Tetrahedron,
25, 1727 (1969).

9) F. B. LaForge and W. F. Barthel, J. Org. Chem., 10, 114 (1945). 